\title{
IMPACT OF POLITICIZATION OF THE EUROPEAN COMMISSION ON THE FUNCTIONING OF THE EUROPEAN UNION
}

\author{
ВПЛИВ ФЕНОМЕНУ ПОЛІТИЗАЦЇ̈ СВРОКОМІСІЇ \\ ФУНКЦІОНУВАННЯ ЄВРОПЕЙСЬКОГО СОЮЗУ
}

HA

\section{ВЛИЯНИЕ ФЕНОМЕНА ПОЛИТИЗАЦИИ ЕВРОКОМИССИИ НА ФУНКЦИОНИРОВАНИЯ ЕВРОПЕЙСКОГО СОЮЗА}

\section{Buromenskiy M.V.}

Doctor of Juridical Science, Professor, Professor of the Department of International Law of Taras Shevchenko National University of Kyiv. E-mail: mykhayloburomenskiy@gmail.com

Otenko P.V.

Postgraduate at the Department of International Law of Yaroslav Mudriy National Law University. E-mail: pavel.otenko@gmail.com

\section{Буроменський М.В.}

Доктор юридичних наук, професор, професор кафедри міжнародного права Київського національного університету імені Тараса Шевченка. E-mail: mykhayloburomenskiy@gmail.com

\section{Отенко П.В.}

Аспирант кафедры международного права Национального юридического университета имени Ярослава Мудрого. E-mail: pavel.otenko@gmail.com

\section{Буроменский М.В.}

Доктор юридических наук, профессор, профессор кафедры международного права Киевского национального университета имени Тараса Шевченко. E-mail: mykhayloburomenskiy@gmail.com

\section{Отенко П.В.}

Аспірант кафедри міжнародного права Національного юридичного університету імені Ярослава Мудрого. Еmail: pavel.otenko@gmail.com

Abstract. Complex and comparative analysis of the election and nomination procedure of Commissioners and the President of the EU Commission has been made from the date of creation of the High Authority within the European Coal and Steal Community until the establishment of the modern EU Commission in accordance with the last amendments that have been made by the Lisbon Treaty. It is proved that due to the entering into force of the Maastricht Treaty, sharpening of the "democratic deficit» problem and because of other political processes at the beginning of 1990 's within the European Communities, European Parliament obtained ample powers and leverage on the functioning, election and nomination procedure of Commissioners and the President of the EU Commission. It is emphasized that election and nomination procedure of Commissioners and the President of the EU Commission is sufficiently politicized and bureaucratized at the contemporary stage of the existence of the European Union. The definition of the phenomenon "politicization of the EU Commission» has been specified. It is outlined that the phenomenon of politicization of the EU Commission has both positive and negative consequences on the EU Commission and the EU as a whole. It is established that "politicization» of the EU Commission may cause disruption of the cornerstone principles on which the EU has been created, first of all those principles that are related to the theory of functionalism in International Law. 
Key words: EU Commission, politicization, impact of politicization, election and nomination procedure of Commissioners and the President of the EU Commission, EU.

Анотація. Комісія Європейського Союзу (Комісія СС) $є$ одним із основних та важливих інститутів Європейського Союзу (ЕС). Комісію $Є C$ досить часто характеризують як «серие євробюрократії», «захисник Договорів Свропейського Союзу» та «рушійною силою європейської інтеграиії». Не зважаючи на широке коло повноважень, реальне місие Комісії в системі органів СС визначається також політичними впливами, які вона отримала у зв'язку з активізацією процесів політизації в Європейських Співтовариствах на початку 1990-х, а потім в СС. Тому в правовій літературі та на практиці жваво дискутуються питання збільшення політичного впливу на Комісію ЄС, зокрема в такому приниипово важливому питанні, як функиіонування, обрання та призначення членів та Президента Комісії СС. Мета статті є здійснення порівняльного аналізу змін в прочедурі обрання та призначення членів та Президента Комісіі СС, починаючи з моменту створення Верховного органу, який діяв в межах Європейського Співтовариства Вугілля та Сталі (ССВС), до сьогоднішніх днів з урахуванням останніх змін, які були внесені Лісабонським договором 1 грудня 2009 року, надання визначення поняттю «політизація Комісії ЄС», здійснення комплексної оцінки впливу політизації Комісії ЄС на ї̈ функиіонування та на процес європейської інтеграції в ичілому. В статті здійснено комплексний порівняльний аналіз процедури обрання та призначення членів та Президента Комісії ЄС з моменту створення Верховного органу, який було створено в рамках $Є С В С$, до становлення сучасної Комісії $Є С$ з урахуванням останніх змін внесених Лісабонським Договором. Доведено, що з набранням чинності Маастрихтського Договору, у зв'язку із загостренням проблеми «дефріииту демократії», а також активізацією інших політичних прочесів на початку 1990-х років в межах Свропейських Співтовариств, Європейський Парламент набув достатньо широких повноважень та важелів впливу на функиіонування, процедуру обрання та призначення членів та Президента Комісії СС. Висвітлено, щу процедура обрання та призначення членів та Президента Комісї ЄС $\epsilon$ політизованою та достатньо бюрократизованою на сучасному етапі існування Свропейського Союзу, на що вказує закріплена в Договорі про ЄС імперативна норма про необхідність Свропейській Раді, при призначенні кандидата на пост Президента Комісіі ЄC, брати до уваги результати останніх виборів до Свропейського Парламенту. Надано власне визначення феномену «політизаџія Комісії СС». Так, з точки зору авторів, можливим $\epsilon$ надання наступного визначення иьвому феномену - ие активна участь та високий ступінь впливу політичних акторів та інститутів на процедуру обрання та призначення складу Комісії Свропейського Союзу, а також на ії функціонування як провідного інституту Європейського Союзу, з одночасним використанням иьього впливу з метою задоволення власних політичних потреб або інтересів. Зазначено, щзо феномен політизації Комісії ЄС має як позитивні, так і негативні наслідки для Комісії ЄС та ЄС. 3 одного боку, політизачія Комісії ЄС може розглядатися як така, що має позитивні риси, зокрема тому, що вона сприяє відкритості історично забюрократизованих інститутів ЄС та можливостям для демократичних впливів на них. 3 іншого боку, політизація Комісії $Є С$ може мати негативний вплив на ї̈ незалежність та неупередженість в процесі прийняття нею важливих рішень. Наприклад, високий рівень «політизації» Комісії СС може завадити їи легітимно забезпечувати дотримання законодавства ЄС та основоположсих Договорів СС разом із Судом справедливості Свропейського Союзу. Охарактеризовано вплив феномену політизації Комісії ЄС на функиіонування Комісії ЄС та ЄС в ичілому. Доведено, щзо подальше розширення «політизаџії» Комісії СС може спричинити, на думку авторів, підрив тих основоположних принцииів, на яких побудований сам СС, передусім пов'язаних з теорією функціоналізму та передбачають чітку відокремленість економічних, соціальних та технічних сфер діяльності від політичної.

Ключові слова: Комісія СС, політизація, вплив політизації, порядок обрання та призначення членів та Президента Комісії ЄС, ЄС. 
Аннотация. Проведен комплексный сравнительный анализ процедуры избрания и назначения членов и Президента Комиссии ЕС с момента создания Верховного органа, который был создан в рамках Европейского Сообщества Угля и Стали, до становления современной Комиссии ЕС с учетом последних изменений, внесенных Лиссабонским Договором. Доказано, что со вступлением в силу Маастрихтского Договора, в связи с обострением проблемы «дефицита демократии», a также активизацией других политических прочессов в начале 1990-х в рамках Европейских Сообществ, Европейский Парламент получил достаточно широкие полномочия $и$ рычаги влияния на функиионирования, процедуру избрания и назначения членов и Президента Комиссии ЕС. Показано, что прочедура избрания и назначения членов и Президента Комиссии ЕС является политизированной $u$ достаточно бюрократизированной на современном этапе существования Европейского Союза. Дано собственное определение понятию «политизация Комиссии ЕС». Указано, что феномен политизаџии Комиссии ЕС имеет как позитивные, так и негативные последствия для Комиссии ЕС и ЕС. Охарактеризовано влияние феномена политизации Комиссии ЕС на функционирования Комиссии ЕС и ЕС в иелом. Доказано, что «политизация» Комиссии ЕС может вызвать подрыв основоположных принципов, на которых построен сам ЕС, прежде всего, связанных с теорией функиионализма в международном праве.

Ключевые слова: Комиссия ЕС, политизаџия, влияние политизации, порядок избрания и назначения членов и Президента Комиссии ЕС, ЕС.

Research problem setting. Commission of the European Union (Commission of the EU) is one of the main institutions of the European Union (EU). Creation of the Commission of the EU and delegation to it the wide terms of reference historically associate with the unique supranational feature of this institution. The supranational feature of the Commission of the EU is manifold and can be traced in its organizational structure, powers and tasks that are conferred on it by the Treaty of the European Union (TEU).

In such a way, according to Art. 17 of the TEU the Commission shall promote the general interest of the Union and take appropriate initiatives to that end [1]. Commission of the EU is frequently characterized as «the heart of euroburaucracy», «the guardian of the Treaties of the EU» and «the engine of the European integration». Commission of the EU is one of the most influential international organizations in the whole world, it is impossible to find the same one [Kassim, Peterson, Bauer, 2013: 1]. In many respects the Commission of the EU is a sui generis institution.

In accordance with Art. 17 of the TEU, Art. 249, 314 of the Treaty on the functioning of the European Union (TFEU), Commission of the EU is conferred with the following powers: the monopoly right of legislative initiative in respect of areas which are fallen within exclusive and common competences of the European Union; drafting annual reports on the actions of the European Union; supervision over the proper use and effective expenditure of the budget of the European Union; mutual supervision with the Court of Justice of the European Union over the implementation and observation of the legislation of the European Union by the Members States; representation of the European Union in external affairs of the EU in areas that are not fallen within the common foreign and security policy as well as conducting of negotiations on the conclusion of treaties where one of the parties is the EU $[1,2]$.

In spite of the wide terms of reference, the real place of the Commission of the EU within the system of the EU institutions is also determined by the political impact, that took place because of the activization of politicization processes within the European Communities at the beginning of the 1990's and then in the EU. For this reason, both in legal literature and in practice the issue on the expansion of the political impact on the Commission of the EU, interalia in such important issues as functioning, election and nomination procedure of Commissioners and the President of the Commission of the EU.

Analysis of the latest researchers and publications. The issue of politicization of the Commission of the EU has been outlined in scientific works of M. Bauer, [12], J. Ege [12], H. Grabbe [14], M. Hartlapp [15], R. Castaldi [13], S. Lehne [14], A. Ortega [17], A. Wille [11], and 
others. Notwithstanding that this issue is an important one, within the mentioned-above scientific works there is the lack of complex comparative analysis of alterations made in the election and nomination procedure of Commissioners and the President of the Commisison of the EU, starting from the date of creation of the European Coal and Steal Community (ECSC) till the last amendments that have been made by the Lisbon Treaty. Accordingly, it is vital to understand the content of the term "politicization of the Commission of the EU", make an appraisal of impact of this phenomenon both on the functioning of the Commission of the EU and on the EU as a whole. Clarification of these issues is significant to the science of the International Law and has a big practical value.

The purpose of the article. The main purpose of the article is to make a comparative analysis of the amendments in the election and nomination procedure of Commissioners and the President of the Commisison of the EU starting from the date of creation of the European Coal and Steal Community (ECSC) till the last amendments that have been made by the Lisbon Treaty; to define the notion of "politicization of the Commission of the EU"; to make a complex assessment of the consequences of the politicization of the Commission of the EU on its functioning and on the process of the European integration as a whole.

Basic research material. The actual predecessor of the contemporary EU was the European Coal and Steal Community (ECSC) which has been created on the $18^{\text {th }}$ of April 1951 by France, West Germany, Italy and Benelux countries by concluding the Treaty of Paris, that came into force on the $23^{\text {rd }}$ of July 1952. For the proper functioning of the ECSC four institutions have been set up, one of which was the High Authority [6].

According to the provisions of the Treaty of Paris, the High Authority shall be composed of nine members designated for six years, chosen for their general competence. Eight members of the High Authority were elected by the governments of the Members States by agreement among themselves. Then these eight members elected the ninth member who should be deemed to be elected if the candidate obtained at least five votes [6]. In addition, the members of the High Authority shall exercise their functions in complete independence, in the general interest of the Community.

In accordance with Art. 11 of the Treaty of Paris the President and the Vice President of the High Authority shall be designated from among the membership of the High Authority for two years, in accordance with the procedure provided for the designation of the members of the High Authority by the governments of the members states.

In order to enhance integration in the fields of economics and atomic energy in 1957 Benelux countries, Germany, France and Italy entered into two Roman treaties: The Treaty establishing European Economic Community (EEC) and the Treaty establishing European Atomic Energy Community (Euratom) that came into force on the $1^{\text {st }}$ of January 1958.

For the proper functioning of these two Communities two separate bodies were set up similarly to the High Authority, each was named "the Commission". The same as in the ECSC, the Commission of the EEC was composed of nine members and the Commission of the Euratom was composed of five members that were elected by the common accord of the members states for fouryears term [7, 5]. The President and the two Vice Presidents of the Commission of the EEC, the President and the Vice President of the Commission of the Euratom were elected among the members of the particular Commission for two-years term by the election procedure prescribed for the election of the members of the particular Commission. As well as the members of the High Authority, members of the Commissions shall exercise their functions in complete independence and be completely impartial.

Due to the conclusion of the Brussels Treaty on the $8^{\text {th }}$ of April 1965, that is better known as the Merger Treaty, which entered into force on the $1^{\text {st }}$ of July 1967, the High Authority of the ECSC and two Commissions that were functioning within the EEC and the Euratom were merged into the one common executive body - the Commission of the European Communities [4]. The total number of members has not been altered. The President and three Vice Presidents of the Commission of the 
European Communities were elected among the members of the Commission of the European Communities by the common accord of the governments of members states.

During the 1990's and 2000's the election and nomination procedure of the President and members of the Commission of the European Communities underwent fundamental changes because of the necessity to put in place reforms interalia institutional reforms that were launched within the European Communities and then in the European Union. During this time period one of the most vexed problem was the problem of "democratic deficit". The "democratic deficit" characterizes the situation when institutions of the EU and their decision-making procedures are not enough democratic and inaccessible to the citizens of the EU [24].

With entering into the legal force of the Maastricht Treaty on the $1^{\text {st }}$ of November 1993 , European Parliament obtained ample powers as well in the election and nomination procedure of Commissioners and the President of the Commission of the European Communities. In this respect, governments of the members states by the common accord elected the President of the Commission after conducting obligatory consultations with the European Parliament. Then governments of the Members States with elected President of the Commission elected other Commissioners. Elected President and Commissioners as a single body shall be accepted by the European Parliament. If the European Parliament gives its consent on the proposed composition of the Commission, the President and Commissioners shall be completely nominated by governments of the Members States by agreement among themselves [10]. Amendments were also made on the term of powers and general number of Commissioners. Pursuant to the Treaty of the EU the President and Commissioners of the Commission shall be elected on the five-years term and the total number shall be seventeen members.

The Amsterdam Treaty, which came into force on the $1^{\text {st }}$ of May 1999, has increased supervisory powers of the European Parliament by granting to it the right to approve the President of the Commission elected by the member states [8]. During the Amsterdam conference members states did not alter the total number of Commissioners. Nevertheless, member states concluded the Protocol on the institutions with the prospect of enlargement of the European Union, where it was specified that the Commission shall comprise one national of each of the Member States.

The Treaty of Nice, which entered into force on the $1^{\text {st }}$ of February 2003, also made significant amendments regarding the election and nomination procedure of the members of the Commission. In such a way, the European Council, acting by a qualified majority, shall nominate the President of the Commission. This nomination shall be approved by the European Parliament. After that, the European Council, acting by a qualified majority and by the common accord with the nominee for President, shall adopt the list of other persons whom it intends to appoint as Members of the Commission. Finally, the President and the other Members of the Commission thus nominated shall be subject as a body to a vote of approval by the European Parliament. After approval by the European Parliament, the President and the other Members of the Commission shall be appointed by the Council of the EU, acting by a qualified majority [9].

When the Lisbon Treaty came into force on the $1^{\text {st }}$ of December 2009 the election and nomination procedure of Commissioners and the President of the Commission of the EU was subject to the fundamental changes and suffered from the political impact. According to para. 7 Art. 17 of the TEU taking into account the elections to the European Parliament, after having held the appropriate consultations, the European Council, acting by a qualified majority, shall propose to the European Parliament a candidate for President of the Commission. This candidate shall be elected by the European Parliament by a majority of its component members. If the candidate obtained required number of votes, the Council of the EU, by common accord with the President-elect, shall adopt the list of the other persons whom it proposes for appointment as members of the Commission. Then, the President of the Commission with other members shall be subject as a body to a vote of consent by the European Parliament. On the basis of this consent the Commission shall be appointed by the European Council, acting by a qualified majority [2]. The Lisbon Treaty also made changes on the total number of Commissioners. In accordance with para. 5 Art. 17 of the TFEU as from $1^{\text {st }}$ November 2014, the Commission shall consist of a number of members, 
including its President and the High Representative of the Union for Foreign Affairs and Security Policy, corresponding to two thirds of the number of Member States, unless the European Council, acting unanimously, decides to alter this number. Nevertheless, the European Council by its decision on 22 of May 2013 adopted a decision by which the number of members of the Commission of the EU shall be equal with the number of members states [3].

In such a way, from the date of entering into force of the Treaty of Lisbon, the election and nomination procedure of Commissioners and the President of the Commission of the EU became both more complicated and bureaucratized as well as politicized. This phenomenon may be traced in the TEU where imperative provision on the obligation of the European Council to take into account the last the elections to the European Parliament when the nomination of the President of the EU Commission is at stake.

Influence of the European Parliament on the Commission of the EU also may be tracked in the ordinary legislative procedure. It often happens that both European Parliament ask the European Commission to present proposals or amend proposals on specific dates, or even suggesting the content of such proposals [Ponzano, Hermanin, Corona, 2012: 36-37]. This right of the European Parliament is specified in Art. 225 of the TFEU. Such practice in certain circumstances prejudices impartiality and objectivity of the Commission's legislative proposals. Despite the fact that the Commission of the EU has the monopoly right of legislative initiative, in some cases the Commission of the EU is obliged to initiate draft legislation within the time limits or with the certain content determined by the European Parliament.

Legal determination and recognition of the European Council in official capacity of one of the EU institutions also play an important role. In accordance with provisions of the Founding Treaties, the decision-making process, predominately has tripartite character. The main actors are Commission of the EU, European Parliament and the Council of the EU. In spite of the fact that the Commission of the EU has the monopoly right of legislative initiative, in most areas the actual ground for proposing legislative initiatives is political willpower of the European Council [Scoutheete, 2011]. It is also possible to draw a conclusion that there is a likelihood of the impact of heads of states and governments who acts in the European Council on the Commission of the EU. The European Council has recently become a formal EU institution, so that it is not only providing 'general guidelines', now it defines detailed policy programmes that then have to be 'implemented' by the other institutions interalia by the Commission of the EU [Bauer, Ege, 2012: 4]. In this respect the Commission of the EU partially loses its positions regarding the monopoly right of legislative initiative.

Summarizing, form the date of entering into force of the Lisbon Treaty the election and nomination procedure of Commissioners and the President of the Commission of the EU underwent significant changes, which provided the European Parliament and the European Council with the opportunity to influence on the functioning, election and nomination procedure of the Commission of the EU as a whole.

The phenomenon of "politicization" of the Commission of the EU is not only a new one but also plays an important role in making an objective assessment regarding the place of the Commission of the EU within the institutional system of the EU. At the current moment scholars have not made a generally recognized definition of this phenomenon despite the vast number of such attempts. Thus, "politicization" may be determined as "the substitution of bureaucratic neutrality by introducing political considerations into the human resource management and direct behavior of civil servants" [Bauer, Ege, 2012: 2]. P. de Wilde considers that "this is the process, that made things be a part of the policy" [Wilde, 2012]. "Politicization" also may be specified as "the process where political actors use administration for their personal gain instead of serving the people's interest [23, p. 4]. Arie Reich characterizes the phenomenon of politicization as "situation, where actions are taken for purposes unrelated or inadequately related to the goals and functions of the particular international organization, but rather stem from the geopolitical goals and strategies of a particular member state or group of member states" [Reich, 2005: 784]. 
Taking into account the mentioned-above definitions, in our opinion the phenomenon "politicization of the Commission of the EU" may be defined in the following way: an active role and highness impact of political actors and institutions on the election and nomination procedure of members of the Commission of the European Union, as well as on its functioning as one of the leading institutions of the European Union, simultaneously with the usage of this influence in order to satisfy their own political interests and needs. The most important issue through the lens of the process of "politicization of the Commission of the EU" was and is its procedural documentation in the legal acts of the European Union which would help to get it from the political shadow and take it to the sphere of legal transparency.

The process of politicization of the Commission of the EU may cause both positive and negative consequences. From the one hand, the politicization of the Commission of the EU may have positive consequences because it promotes openness of the historically bureaucratized institution of the EU and increases democratic impact on it. Politicization also plays an important role in solving the problem of "democratic deficit" which emerged in the beginning of the 1990's. The fact of granting to the European Parliament the wide terms of reference concerning the Commission of the EU provides citizen of the EU with the opportunity to exercise indirect control over its composition and actions by directly elected members of the European Parliament [Ortega, 2014].

In addition, alterations made by the Lisbon Treaty on the election and nomination procedure of the President and Commissioners of the Commission of the EU abate influence of the European Council on the functioning of other institutions of the EU and the EU as a whole. In such a way, these alterations strengthened positions of the European Parliament in relation to the historically strong European Council. It helped to lessen the disbalance of powers within the interinstitutional relationships. It also strengthened the status of supranational institutions such as the European Parliament in relation to the intergovernmental ones, interalia the European Council. The main goals of such alterations were to return the sovereignty to the citizens of the EU and gradually balance the excessive powers of the European Council by the democratically elected European Parliament [Castaldi, 2013: 9].

From the other hand, politicization of the Commission of the EU may cause the negative influence on its independence and impartiality during the process of making significant decisions. For instance, the high degree of "politicization" of the Commission of the EU may prevent it from maintaining the due supervision of Union law under the control of the Court of Justice of the European Union. Moreover, very "politicized" Commission of the EU would not comply with the principles of "complete independence" in accordance with Art. 17 of the TEU. Consequently, the situation may occur when a newly elected President of the Commission of the EU who before the election was one of the members of a political party will impose sanctions regarding national governments that are related to another political power. Such decisions cannot be considered to be impartial and objective. The Commission of the EU has obtained new powers as a result of the euro crisis - but to exercise them effectively, it needs to act as referee in the political game, not as captain of one of the teams [Grabbe, Lehne, 2013: 2].

In our opinion the main problem of "politicization" of the Commission of the EU is a likelihood of disruption of the founding principles on which the EU has been set up. First of all, it relates to the principles that are connected with the theory of functionalism which emphasizes the importance of such principles in the achievement of the international order on the basis of nonpolitical international organizations dealing with specific economic, social, technical, or humanitarian functions [Reich, 2005: 783]. It implies that economic, social and technical spheres shall be explicitly separated from the political one.

The proper functioning of the Commission of the EU may only be attained through the compliance with the mentioned-above principles of the theory of functionalism. To sum up, "politicization" of the Commission of the EU poses a threat to the serious disfunction of both the Commission of the EU and of the founding principles of the EU. 
Conclusions. The Commission of the EU is one of seven main institutions of the European Union. According to the provisions of the Treaty of European Union the Commission shall promote general interest of the Union and take appropriate initiatives to that end. Consequently, this institution in itself shall be independent, impartial and objective. However, the comparative analysis of the Founding Treaties which came into force during the last thirty years has shown that starting from the 1990's simultaneously with politicization processes within the European Communities and then in the European Union, the facts of strengthening of the political impact on the Commission of the EU especially in the course of the election and nomination procedure of Commissioners and President of the Commission of the EU and on its functioning as an institution may be observed.

Within the scientific literature it is impossible to find a generally recognized definition of the term "politicization of the Commission of the EU". Taking into account various definitions of "politicization" it is possible to give the following definition of the phenomenon "politicization of the Commission of the EU": an active role and highness impact of political actors and institutions on the election and nomination procedure of members of the Commission of the European Union, as well as on its functioning as one of the leading institutions of the European Union, simultaneously with the usage of this influence in order to satisfy their own political interests and needs.

"Politicization" of the Commission of the EU may cause both positive and negative consequences. The positive aspect of it is the expansion of transparency and openness in the activity of the main bureaucratized institution of the EU.

The negative aspect of "politicization" of the Commission of the EU is a likelihood of influence on its independence and impartiality during the decision-making process.

In our opinion, gradual extension of "politicization" of the Commission of the EU may cause erosion of founding principles on which the EU has been set up. First of all, those that are connected to the theory of functionalism and envisage clear separation of economic, social and technical spheres from the political one.

\section{References}

1. Consolidated version of the Treaty on European Union (2012), Official Journal of the European Union, 55:13-47.

2. Consolidated version of the Treaty on the Functioning of the European Union (2012), Official Journal of the European Union. 55: 47-201.

3. European Council decision of 22 May 2013 concerning the number of members of the European Commission (2013), Official Journal of the European Union, 56: 98.

4. Treaty establishing a Single Council and a Single Commission of the European Communities, $<$ https://eur-lex.europa.eu/legal-content/EN/TXT/PDF/?uri=CELEX:11965F\&from=CS/>.

5. Treaty establishing the European Atomic Energy Community, Virtual centre for knowledge on Europe,

<https://www.cvce.eu/en/obj/treaty_establishing_the_european_atomic_energy_community_rome_25_marc h_1957-en-a3390764-3e75-421b-9c85-f52de5a14c2f.html>.

6. Treaty establishing the European Coal and Steel Community, Virtual centre for knowledge on Europe: $\quad<$ https://www.cvce.eu/content/publication/1997/10/13/11a21305-941e-49d7-a171ed5be548cd58/publishable_en.pdf $>$.

7. Treaty establishing the European Economic Community, Virtual centre for knowledge on Europe, <https://www.cvce.eu/en/obj/treaty_establishing_the_european_economic_community_rome_25_march_195 7-en-cca6ba28-0bf3-4ce6-8a76-6b0b3252696e.html>.

8. Treaty of Amsterdam amending the Treaty on European Union, the treaties establishing the European Communities and certain related acts (1997), Official Journal of the European Communities, 40: $1-145$.

9. Treaty of Nice amending the Treaty on European Union, the Treaties establishing the European Communities and certain related acts (2001), Official Journal of the European Communities, 44: 1-87. 
10. Treaty on European Union, signed at Maastricht on 7 February 1992 (1992), Official Journal of the European Communities, 35: 1-112.

11. Anchrit W. (2012) 'The politicization of the EU Commission: democratic control and the dynamics of executive selection', International Review of Administrative sciences 78: 383-402.

12. Bauer W.M., Ege J. (2012) 'Politicization within the European Commission's Bureaucracy', International Review of Administrative Sciences 78: 403-424.

13. Castaldi R. (2013) 'The politicization of the European elections and its potential effects on the EU', Perspectives on Federalism 5: 1-9.

14. Grabbe H., Lehne S. (2013) 'The 2014 European elections Why a partisan Commission president would be bad for the EU'. Centre for European reform, <https://carnegieendowment.org/files/esy_commissionpres_11oct13-7937.pdf>.

15. Hartlapp M. (2015) 'Politicization of the European Commission: When, How, and with What Impact?', in Bauer M.W., Trondal J. (eds) The Palgrave Handbook of the European Administrative System, pp. 145-160. London: Palgrave Macmillan.

16. Kassim H., Peterson J., Bauer W.M., Connolly S., Dehousse R., Hooghe L. and Thompson A. (2013) The European Commission of the Twenty-First Century, Oxford: Oxford University Press.

17. Ortega A. 'The European Commission's politicization', Elcano Blog, <https://blog.realinstitutoelcano.org/en/european-commissions-politicisation/>.

18. P. de Wilde. (2007) 'Politicisation of European Integration: Bringing the Process into Focus', University of Oslo ARENA Working Paper 2007/18: 1-33.

19. Perocevic K. (2017) 'European Union Legal Nature: EU as sui generis - a playplus-like society', Intereulaweast Journal. IV (2): 101 - 116.

20. Ponzano P., Hermanin C. and Corona D. (2012) 'The power of initiative of the European Commission: A Progressive Erosion?', Paris: Notre Europe.

21. Reich A. (2005) 'The threat of politicization of the WTO', University of Pennsylvania Journal of International Law 26: 779-814.

22. Scoutheete P. (2011) 'Decision-making in the Union'. Notre Europe, <http://www.institutdelors.eu/wp-content/uploads/2018/01/bref24-deschoutheete-en.pdf>.

23. Zahid H., Mehedi H. (2011) 'Politicization of Administration and Its Impacts on Administrative Performance', University of Dhaka, <https://www.academia.edu/20948601/Politicization_of_Administration_and_Its_Impacts_on_Administrativ e_Performance>.

24. Glossary of summaries, <https://eur-lex.europa.eu/summary/glossary/democratic_deficit.html>. 